\title{
High pH in shallow-water macroalgal habitats
}

\author{
Anne Lise Middelboe*, Per Juel Hansen \\ Marine Biological Laboratory, University of Copenhagen, Strandpromenaden 5, 3000 Helsingør, Denmark
}

\begin{abstract}
The aim of this study was to evaluate seasonal and diurnal variability in $\mathrm{pH}$ and inorganic carbon in shallow-water macroalgal habitats and to evaluate the importance of high $\mathrm{pH}$ for macroalgal photosynthesis. Seasonal variations in $\mathrm{pH}$, oxygen saturation and inorganic carbon concentration were measured at an exposed and a sheltered shallow-water (0 to $1 \mathrm{~m}$ ) macroalgal habitat. Daytime pH was significantly higher in spring, summer and autumn than in winter at both study sites. Diurnal measurements at the most exposed site showed significantly higher $\mathrm{pH}$ during the day than during the night. The diurnal variations were largest in shallow water and decreased with increasing water depth. High $\mathrm{pH}$ resulted in periodically low concentrations of available inorganic carbon in summer (as low as $1.3 \mathrm{mmol}\left[\mathrm{CO}_{2}+\mathrm{HCO}_{3}^{-}\right] \mathrm{l}^{-1}$ ). Photosynthesis as a function of inorganic carbon concentrations was measured at pH 8 and 9.3 for 4 common macroalgal species (Fucus vesiculosus, F. serratus, Ceramium rubrum, Ulva sp.). Photosynthesis in these species was not limited by natural concentrations of inorganic carbon, but maximum photosynthesis and inorganic carbon concentrations at saturation were lower when measured at $\mathrm{pH} 9.3$ than at $\mathrm{pH}$ 8. Our results suggest that $\mathrm{pH}$ is higher in natural shallow-water habitats than previously thought, and that high $\mathrm{pH}$ has a direct effect on photosynthesis that cannot be accounted for by low availability of inorganic carbon.
\end{abstract}

KEY WORDS: $\mathrm{pH} \cdot$ Seasonal variations $\cdot$ Diurnal variations $\cdot$ Macroalgae $\cdot$ Photosynthesis

Resale or republication not permitted without written consent of the publisher

\section{INTRODUCTION}

$\mathrm{pH}$ in the sea is usually considered to be stable at around 8 to 8.2 (Skirrow 1975), due to the high buffering capacity of seawater. Recent studies have, however, documented that $\mathrm{pH}$ is not always stable. Measurements in coastal areas show that $\mathrm{pH}$ can increase to between 9 and 10 during phytoplankton blooms (Hansen 2002, Hinga 2002). In a Danish estuary, Mariager Fjord, the average summer pH was 8.8 in the years 1990 to 1999, and periodically on sunny and calm days pH was as high as 9.75 (Hansen 2002). In other areas, $\mathrm{pH}$ can be high year-round, as for example in a Portuguese coastal lagoon (Macedo et al. 2001).

Focus has thus far been on open water, but $\mathrm{pH}$ may be even higher in dense populations of coastal macroalgae. High pH may occur at high irradiance (and photosynthesis) in stagnant waters, as expected for shallow-water macroalgal communities in the summer. There are, however, but few measurements of $\mathrm{pH}$ in macroalgal populations. In populations of Fucus vesi- culosus in the Baltic Sea, $\mathrm{pH}$ was about 9 in summer (Pearson et al. 1998). In dense floating macroalgae in a brackish coastal lagoon in the Ebro River Delta (NE Spain) maximum pH was 9 to 9.5 (Menendez et al. 2001) and $\mathrm{pH}$ values as high as 9.8 to 10.1 have been reported from isolated rock pools in Sweden (Björk et al. 2004). Even though $\mathrm{pH}$ has never been measured systematically and continuously in natural macroalgal habitats, these sporadic measurements suggest that $\mathrm{pH}$ occasionally is high.

In shallow-water macroalgal habitats the frequency of high $\mathrm{pH}$ will depend on the degree of wave exposure at the site and on seasonal and diurnal variability in photosynthetic production. $\mathrm{pH}$ is probably highest in sheltered habitats such as lagoons and estuaries where the exchange of water with the surroundings and wind exposure is small, while wave-exposed sites with a large exchange of water may be less influenced by photosynthetic processes at the site. Seasonally we would expect high $\mathrm{pH}$ during spring and summer when irradiance and temperature are optimal for 
photosynthesis (Middelboe et al. 2006). pH may also show diurnal variations, with high $\mathrm{pH}$ during daylight hours and lower $\mathrm{pH}$ during the night when respiratory processes dominate. Such diurnal variability should be highest in the shallowest water and less pronounced in deeper water, where respiratory processes on the sea bottom are relatively less dominant.

Periods of high $\mathrm{pH}$ will occur when photosynthetic production is high and carbon dioxide is removed from the system by rubisco, causing a decrease in total inorganic carbon availability and an increase in $\mathrm{pH}$. In seawater, inorganic carbon is present as a mixture of $\mathrm{CO}_{2}$, $\mathrm{HCO}_{3}{ }^{-}$and $\mathrm{CO}_{3}{ }^{2-}$, together termed dissolved inorganic carbon (DIC). The relative amount depends on the salinity, temperature and $\mathrm{pH}$ of the seawater (Stumm \& Morgan 1996). In natural highly saline seawater at $\mathrm{pH}$ $8.2, \mathrm{HCO}_{3}{ }^{-}$makes up about $95 \%$ of DIC, and $\mathrm{CO}_{2}$ only about $1 \%$, corresponding to ca. $14 \mu \mathrm{mol} \mathrm{l}^{-1}$ in oceanic seawater with $2 \mathrm{mmol} \mathrm{l^{-1 }}$ DIC. The amount of $\mathrm{CO}_{2}$, however, decreases rapidly with increasing $\mathrm{pH}$ and only $\sim 1.6 \mu \mathrm{mol} \mathrm{CO} \mathrm{Cl}^{-1}$ remains at $\mathrm{pH} 9$.

Some macroalgal species belonging to the Rhodophyceae seem to rely on passive diffusion of $\mathrm{CO}_{2}$ as their only source of inorganic carbon for photosynthesis, and these species are unable to photosynthesize at high pH (Maberly 1990, Johnston et al. 1992, Raven et al. 2005). These species are typically found in subtidal waters, where $\mathrm{pH}$ is stable at around 8 to 8.2 . Most macroalgae have, however, evolved mechanisms to utilize $\mathrm{HCO}_{3}{ }^{-}$as a possible alternative source of inorganic carbon (called carbon concentrating mechanisms, CCM). However, these mechanisms are not necessarily effective at high $\mathrm{pH}$. For example, extracellular carbonic anhydrase as a mechanism for $\mathrm{HCO}_{3}{ }^{-}$ uptake does not operate at high $\mathrm{pH}$, because the enzyme only accelerates the conversion from $\mathrm{HCO}_{3}{ }^{-}$to $\mathrm{CO}_{2}$, and the $\mathrm{CO}_{2}$ pool is still very small at high $\mathrm{pH}$. Moreover, the direct $\mathrm{HCO}_{3}{ }^{-}$uptake of opportunistic green algae has also been shown to be less effective at high pH (Axelsson et al. 1995, 1999). Therefore, although most intertidal species have been shown to photosynthesize at high pH (Maberly 1990, Murru \& Sandgren 2004), their photosynthetic rates may be reduced.

The aim of this study was to evaluate seasonal and diurnal variability in $\mathrm{pH}$ and inorganic carbon availability in shallow-water macroalgal habitats and to test the effect of high $\mathrm{pH}$ on photosynthesis of 4 macroalgal species (Fucus vesiculosus, F. serratus, Ceramium rubrum and Ulva spp.) that are among the dominant macroalgal species in these habitats. We hypothesized that: (1) pH would be higher at a wave-sheltered than at a wave-exposed study site; (2) pH would be highest and inorganic carbon availability lowest during spring and summer; (3) pH would be highest and inorganic carbon concentrations lowest during the day compared to night; (4) diurnal variability in $\mathrm{pH}$ would decrease with increasing water depth; and (5) high $\mathrm{pH}$ would restrict photosynthesis in shallow water.

\section{MATERIALS AND METHODS}

Study site. Two shallow water sites $(0$ to $100 \mathrm{~cm}$ depth) that differed in wave exposure, bottom topography and macroalgal density were chosen for the study. Both sites were situated in inshore Danish waters where the tidal range is very small $(10 \mathrm{~cm})$. One site was a wave-exposed boulder reef in Aalsgaarde, on the northern coast of Zealand, Denmark, with relatively steep bottom topography. The boulder reef was densely covered with species-rich macroalgal communities dominated by Fucus species (Middelboe et al. 2006). The other site was a sheltered, shallow-water area in Kildebakkerne in the estuary Roskilde Fjord, Denmark. This site had a very homogeneous bottom topography and, at about $70 \mathrm{~m}$ from the coast, the water depth was only about $1 \mathrm{~m}$. At this site low densities of macroalgae (mainly Fucus vesiculosus) were found on small and large stones scattered on the sandy bottom.

Seasonal variations in physico-chemical parameters. The total daily values of global radiation $\left(\mathrm{W} \mathrm{m}^{-2}\right)$ were measured by the Danish Meterological Institute at Sjælsmark about $25 \mathrm{~km}$ from the exposed study site and $30 \mathrm{~km}$ from the sheltered study site. Global radiation data was converted to photosynthetically active radiation (PAR) (conversion factor 0.45, Gonzalez \& Calbo 2002).

$\mathrm{pH}$, temperature, oxygen concentrations and salinity were measured at the 2 study sites at weekly or fortnightly (during winter) intervals from August to November 2004 and again from April 2005 to March 2006. At each site $\mathrm{pH}$, temperature and oxygen concentrations were measured at water depths from 10 to $100 \mathrm{~cm}$ with a hand-held pH-Oxy meter (pH/Oxy 340i, WTW). Salinity was measured with a hand refractometer (Atago). Inorganic carbon concentrations were measured from June 2005 to March 2006. Water samples (in triplicate) for later inorganic carbon determination were taken from the water column at $20 \mathrm{~cm}$ depth using a syringe and immediately fixed with $20 \mu \mathrm{l}$ $\mathrm{Hg}_{2} \mathrm{Cl}_{2}$ in small gas-tight glass bottles $(2 \mathrm{ml})$ and kept dark and cool until analysis. The total inorganic carbon concentrations were measured with an infrared gasanalyzer (ADC $225 \mathrm{MK} 3$ ). Available inorganic carbon concentrations $\left(\mathrm{CO}_{2}+\mathrm{HCO}_{3}{ }^{-}\right)$were calculated from total inorganic carbon concentrations, $\mathrm{pH}$, salinity and temperature according to Mackereth et al. (1978) and Plath et al. (1980). 
Diurnal variations in physico-chemical parameters. Diurnal measurements of the physico-chemical parameters of the seawater were made in late spring (24 to 28 May 2005) at the wave-exposed study site. $\mathrm{pH}$ and temperature were measured every $10 \mathrm{~min}$ and automatically logged with portable $\mathrm{pH}$ meters $\mathrm{(pH} 340 \mathrm{i}$ and pH/Oxy 340i, WTW) at water depths of 20, 40 and $60 \mathrm{~cm}$. Oxygen concentrations were measured at $40 \mathrm{~cm}$ depth only. Salinity was measured and water samples taken for later inorganic carbon determination (same procedure as for seasonal measurements) 4 times $\mathrm{d}^{-1}$.

Macroalgal photosynthesis. The macroalgae Fucus vesiculosus, F. serratus, Ceramium rubrum and Ulva spp. were chosen to study the importance of high $\mathrm{pH}$ and inorganic carbon concentrations for macroalgal photosynthesis. Macroalgal specimens were carefully collected by hand from the exposed study site at 0.5 to $1 \mathrm{~m}$ water depth. The algae were kept in aerated and recycling seawater $\left(11^{\circ} \mathrm{C}\right)$ until used in experiments. Only healthy material with no visible epiphytes was used.

A closed cylindrical Plexiglas chamber $(50 \mathrm{ml})$ was used for measuring the photosynthesis-inorganic carbon response of thallus pieces (50 to $400 \mathrm{mg}$ wet weight depending on the species) at $\mathrm{pH} 8$ and 9.3. Algae were fixed horizontally on a net in the chamber and stirring was provided by a magnetic stirrer bar. Incident irradiance of $500 \mu \mathrm{mol}$ photons $\mathrm{m}^{-2} \mathrm{~s}^{-1}$ on the thallus surface was supplied by a halogen light source (Schott KL 2500 LCD). Measurements were performed in natural seawater and a constant-temperature cooling jacket surrounding the photosynthesis chamber ensured that temperature stayed within $15 \pm 0.5^{\circ} \mathrm{C}$, corresponding to the ambient seawater temperature at the time of measurements (October). Initially the freshly collected algal thallus was illuminated in DICfree seawater for 3 to $15 \mathrm{~h}$ (depending on species) to ensure that the internal carbon pool was depleted. This was assumed to have occurred when no photosynthesis could be measured in DIC-free water. DIC-free seawater was obtained by adjusting the seawater to $\mathrm{pH} \sim 3$ with $\mathrm{HCl}$ and aerating over night. $\mathrm{NaHCO}_{3}$ was then added and the $\mathrm{pH}$ adjusted with freshly prepared $\mathrm{NaOH}$. Photosynthetic rates at different levels of inorganic carbon were measured in steps after injection of small amounts of $0.5 \mathrm{~mol} \mathrm{l}^{-1} \mathrm{NaHCO}_{3}$. Concentrations of DIC after $\mathrm{NaHCO}_{3}$ injection were tested in a separate experiment and the mean values of 3 replicates were used in data analysis. In order to keep pH stable (mean $\pm 95 \%$ confidence limits, $C L=8.03 \pm 0.04$ and $9.3 \pm 0.03$ ) during measurements, $\mathrm{HCl}$ and freshly prepared $\mathrm{NaOH}$ were injected during the experiment. For each species initial experiments were set up to measure the change in $\mathrm{pH}$ during photosynthesis and $\mathrm{NaHCO}_{3}{ }^{-}$addition, and to determine the amount of
$\mathrm{HCl}$ and $\mathrm{NaOH}$ needed to adjust to the desired $\mathrm{pH}$ during experiments. This procedure was chosen because the use of buffers may influence the mechanisms of inorganic carbon uptake (Hellblom et al. 2001). All measurements were in triplicate.

Photosynthetic production was measured as oxygen evolution rates by a Clark-type microsensor (Revsbech 1989) connected to a picoamperemeter (Unisence AS) and a chart recorder. Net photosynthetic production of thalli was calculated from the linear increase in oxygen concentration as a function of time after constant rates had been attained in each case. Measurements were expressed in units of oxygen $\mathrm{g}^{-1}$ thallus dry wt.

Photosynthetic production as a function of inorganic carbon was measured for algae that were not acclimated to $\mathrm{pH}$ 9.3. To evaluate the importance of acclimatization we carried out an experiment with Fucus serratus, which had been acclimated slowly to $\mathrm{pH} 9.3$ by an increase of $0.25 \mathrm{pH} \mathrm{d}^{-1}$. The algae were placed in $260 \mathrm{ml}$ tissue culture bottles and mounted on a wheel (1 rpm) to ensure continuous mixing of water in the bottle and decrease the diffusion boundary layer around the algae. During acclimatization algae were kept at a temperature of $15 \pm 0.5^{\circ} \mathrm{C}$ and illuminated with $200 \mu \mathrm{mol}$ photons $\mathrm{m}^{-2} \mathrm{~s}^{-1}$ in a $16 \mathrm{~h}$ light:8 h dark cycle, using white fluorescence lamps. Photosynthesis of the acclimated algae was measured at pH 8 and 9.3. For comparison other pieces of thallus received the same treatment, but $\mathrm{pH}$ was kept constant at 8. All measurements were in triplicate.

Data analysis. Differences between mean seasonal values of $\mathrm{pH}, \mathrm{O}_{2}$ saturation and inorganic carbon concentrations were tested using 1-way ANOVA and subsequently Tukey's multiple comparison tests. Not all data showed homogeneity of variance, (an assumption of analysis of variance) and therefore the differences between medians were also tested using the non-parametric Kruskal-Wallis and Dunn's multiple comparison tests. Regression analyses between $\mathrm{pH}$ and temperature and daily irradiance between October and April were used to determine whether temperature or irradiance was the main cause of changes in $\mathrm{pH}$ during spring and autumn. Diurnal variations and differences between depths were tested using non-parametric tests (Kruskal-Wallis 1-way analysis of variance on ranks and Mann-Whitney rank sum test).

Photosynthesis $(P)$ as a function of inorganic carbon concentrations (DIC or $\mathrm{CO}_{2}+\mathrm{HCO}_{3}{ }^{-}$) was fitted to a classical Michaelis-Menten equation:

$$
P=\frac{P_{\max } \times \text { DIC }}{K_{\mathrm{m}}+\text { DIC }}
$$

where $P_{\max }$ is the maximum photosynthetic rate and $K_{\mathrm{m}}$ is the inorganic carbon concentration required to reach half maximum photosynthesis. 


\section{RESULTS}

\section{Seasonal variability}

Irradiance ranged from 0.3 to $11 \mathrm{~mol}$ photons $\mathrm{m}^{-2} \mathrm{~d}^{-1}$ in mid-winter to 13 to $62 \mathrm{~mol}$ photons $\mathrm{m}^{-2} \mathrm{~d}^{-1}$ in midsummer (Fig. 1). Temperature ranged from 3 to $21^{\circ} \mathrm{C}$ at the wave-exposed site and from 0 to $30^{\circ} \mathrm{C}$ at the sheltered site (Fig. 2). Salinity was similar at the 2 sites and varied from 10 to $28 \mathrm{psu}$, with the lowest values during the summer months (Fig. 2).

Average seawater $\mathrm{pH}$ and $\mathrm{O}_{2}$ saturation were statistically significantly different between seasons on both the wave-exposed and the sheltered site (Fig. 3, Table 1). pH was lowest in winter months (December to February), somewhat higher in the autumn (September to November) and spring (March to May), but highest during summer months (June to August). pH increased in early spring when the seawater temperature was still low (about $2^{\circ} \mathrm{C}$ ), and irradiance increased above $10 \mathrm{~mol}$ photons $\mathrm{m}^{-2} \mathrm{~d}^{-1}$. In the period of elevated $\mathrm{pH}$, the highest $\mathrm{pH}$ values were found close to the coastline, while the lowest values were found further seawards at $100 \mathrm{~cm}$ depth. In Fig. 3, different $\mathrm{pH}$ values for the same sampling occasion represent different depths. The differences sometimes exceeded $1 \mathrm{pH}$. The overall average was slightly but significantly (Student's $t$-test,

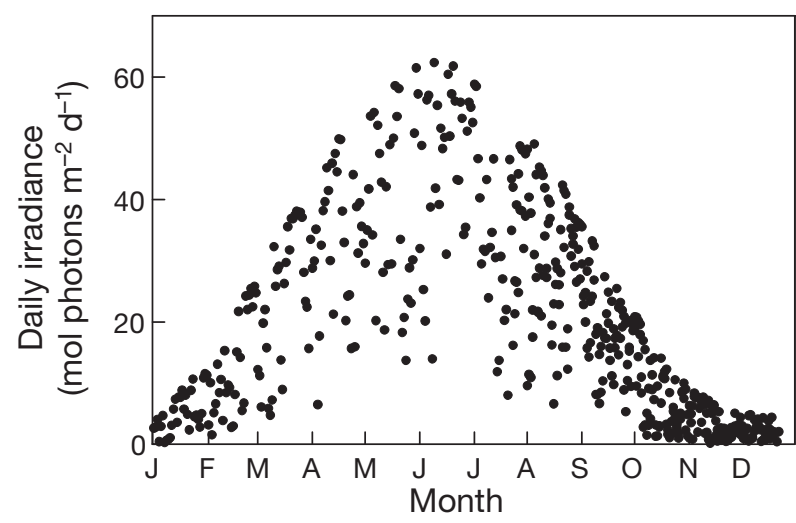

Fig. 1. Seasonal variations in daily irradiance (mol photons $\mathrm{m}^{-2} \mathrm{~d}^{-1}$ ), based on total daily values of global radiation $\left(\mathrm{W} \mathrm{m}^{-2}\right)$ measured by Danish Meterological Institute at Sjælsmark (located about $25 \mathrm{~km}$ from exposed site and $30 \mathrm{~km}$ from sheltered site)

$\mathrm{p}<0.0001)$ higher at the sheltered $(8.65 \pm 0.01)$ than at the wave-exposed $(8.53 \pm 0.02)$ site.

Increases in daily irradiance $\left(I\right.$, mol photons $\left.\mathrm{m}^{-2} \mathrm{~s}^{-1}\right)$ were paralleled by highly significant increases in $\mathrm{pH}_{i} \mathrm{pH}=-175( \pm 29.9)+I \times 22.3( \pm 3.6), \mathrm{R}^{2}=0.26$, $\mathrm{p}<0.0001$ ), while there was no significant relationship with temperature $\left(R^{2}=0.01\right.$ and $\left.p=0.21\right)$.

$\mathrm{O}_{2}$ saturation showed the same seasonality and variation with depth as $\mathrm{pH}$ (Fig. 3, Table 1). It was sig-
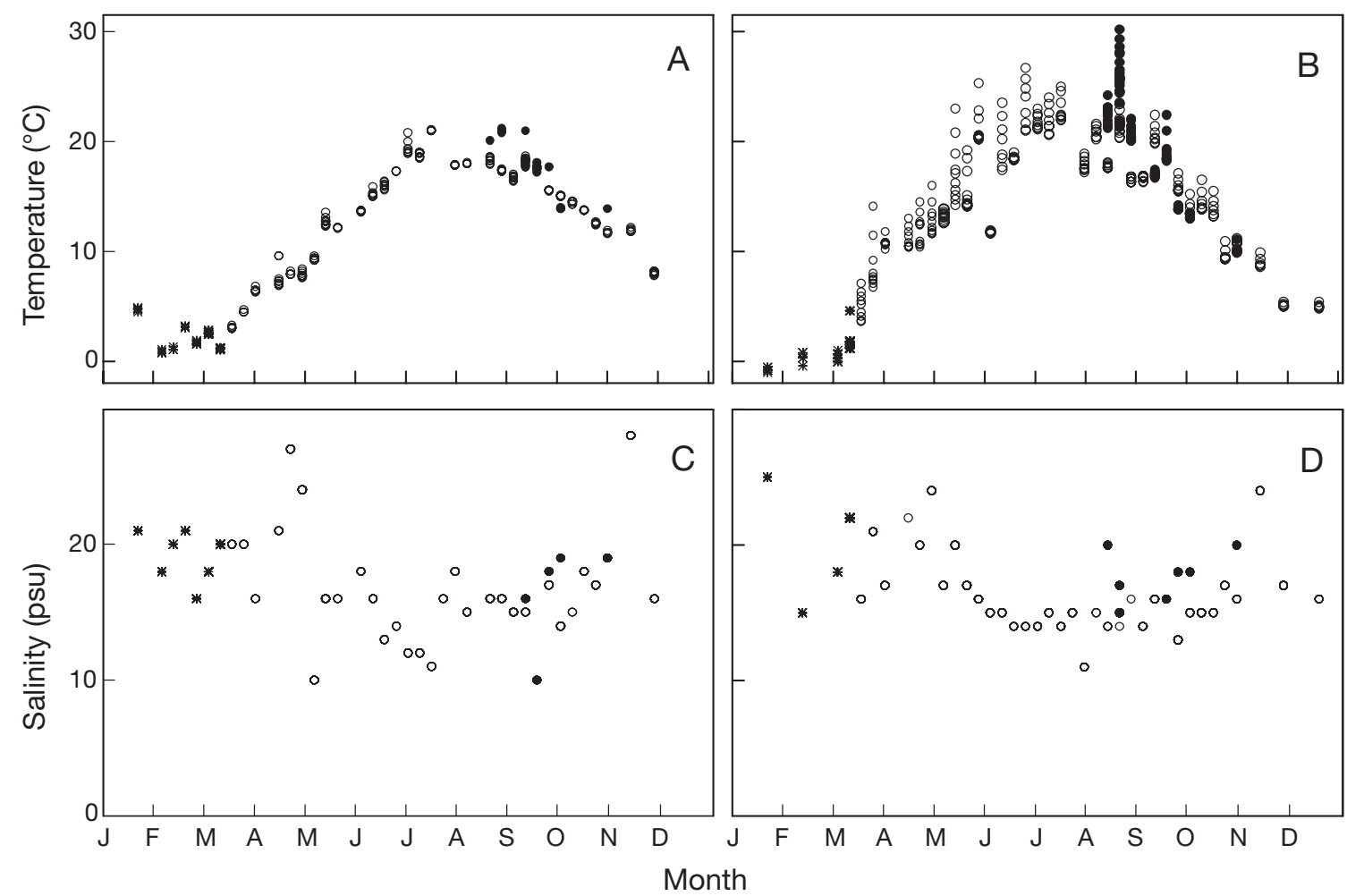

Fig. 2. Seasonal variations in seawater temperature $\left({ }^{\circ} \mathrm{C}\right)$ and salinity $(\mathrm{psu})$ at $(\mathrm{A}, \mathrm{C})$ wave-exposed and $(\mathrm{B}, \mathrm{D})$ sheltered sites in (•) 2004, (O) 2005 and (*) 2006 

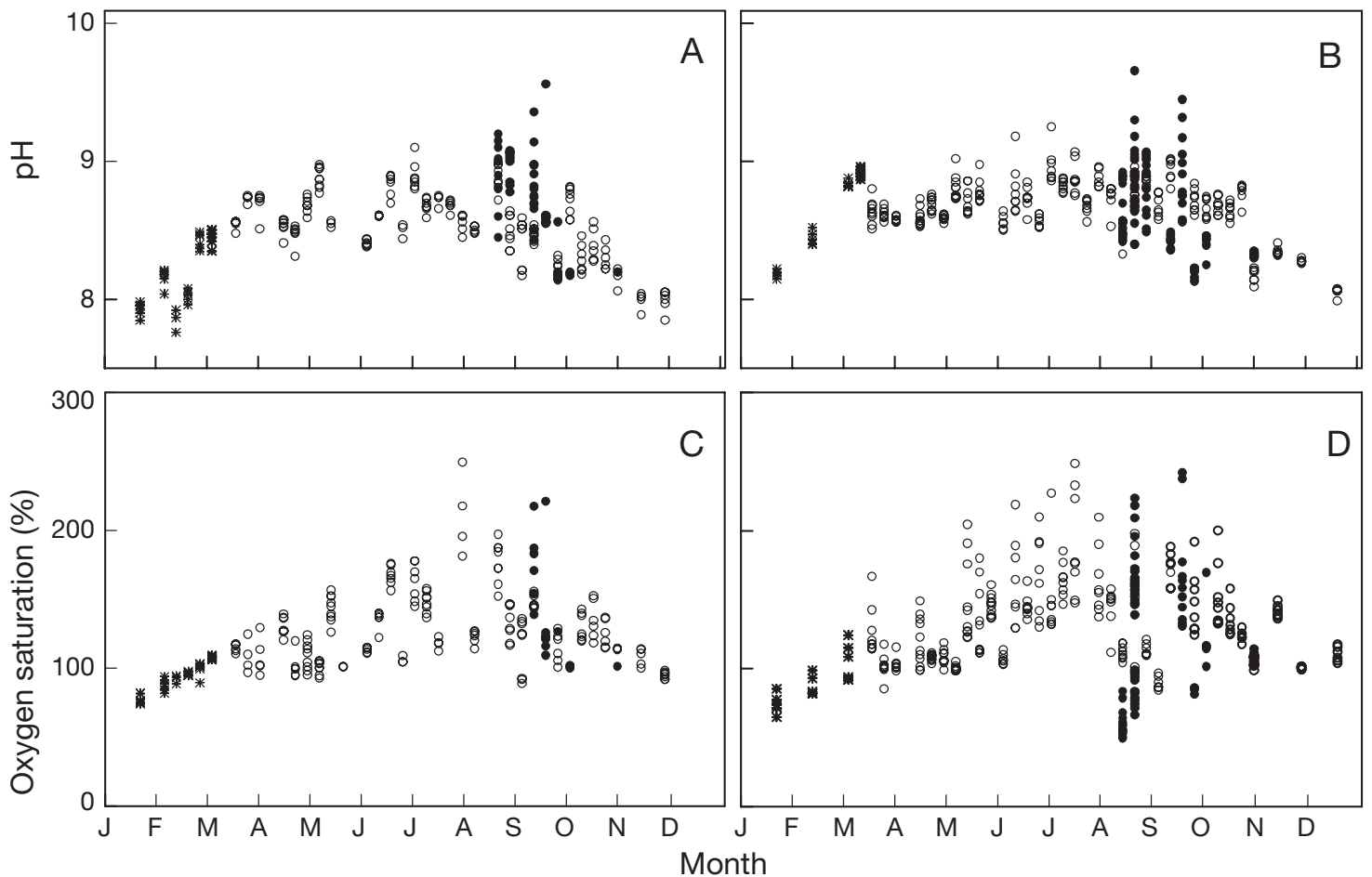

Fig. 3. Seasonal variations in seawater $\mathrm{pH}$ and $\mathrm{O}_{2}$ saturation $(\%)$ at $(\mathrm{A}, \mathrm{C})$ wave-exposed and $(\mathrm{B}, \mathrm{D})$ sheltered sites in $(\bullet) 2004$, (O) 2005 and (*) 2006. Different values on same sampling occasion represent different water depths (10 to $100 \mathrm{~cm})$ with highest $\mathrm{pH}$ and $\mathrm{O}_{2}$ saturation values in shallowest waters

nificantly lower in winter than in summer, but there was no significant difference between spring and autumn. $\mathrm{O}_{2}$ saturation was not significantly different between the wave-exposed and the sheltered site.

Inorganic carbon concentrations showed large variability between sampling days (Fig. 4, Table 1). In general the inorganic carbon concentration was high at all times of the year but during the summer low inorganic carbon concentrations (minimum $1.65 \mathrm{mmol}$ DIC $\mathrm{l}^{-1}$ ) were frequent. Due to the elevated $\mathrm{pH}$ during spring, summer and autumn, the average concentrations of available inorganic carbon were low during these months; the lowest concentration measured was $1.30 \mathrm{mmol}\left[\mathrm{CO}_{2}+\mathrm{HCO}_{3}^{-}\right] \mathrm{l}^{-1}$ at both sites. There were, however, no significant differences between average seasonal inorganic carbon concentrations at the wave-exposed site but at the sheltered site average summer concentrations of DIC and $\mathrm{CO}_{2}$ $+\mathrm{HCO}_{3}^{-}$were significantly higher than average spring values.

Table 1. Seasonal mean $\left( \pm 95 \%\right.$ confidence limits; CL) differences between seasons in $\mathrm{pH}, \mathrm{O}_{2}$ saturation, dissolved inorganic carbon (DIC) and available inorganic carbon $\left(\mathrm{CO}_{2}+\mathrm{HCO}_{3}^{-}\right)$at wave-exposed and sheltered sites. Levels of significance (1-way ANOVA and Kruskal-Wallis, KW test) are also shown. Different superscripts within rows indicate values that differed in statistical tests. ns: not significant

\begin{tabular}{|c|c|c|c|c|c|c|}
\hline \multirow[t]{2}{*}{ Parameter } & \multirow{2}{*}{$\begin{array}{c}\text { Winter } \\
\text { (Dec-Feb) }\end{array}$} & \multirow{2}{*}{$\begin{array}{c}\text { Spring } \\
\text { (Mar-May) }\end{array}$} & \multirow{2}{*}{$\begin{array}{l}\text { Summer } \\
\text { (Jun-Aug) }\end{array}$} & \multirow{2}{*}{$\begin{array}{l}\text { Autumn } \\
\text { (Sep-Nov) }\end{array}$} & \multicolumn{2}{|c|}{ p-value } \\
\hline & & & & & ANOVA & KW \\
\hline $\begin{array}{l}\text { Wave-exposed site } \\
\text { pH }\end{array}$ & $8.11( \pm 0.087)^{\mathrm{a}}$ & $8.57( \pm 0.038)^{b}$ & $8.77( \pm 0.053)^{\mathrm{C}}$ & $8.41( \pm 0.058)^{\mathrm{d}}$ & $<0.0001$ & $<0.0001$ \\
\hline $\mathrm{O}_{2}$ saturation $(\%)$ & $78( \pm 3.6)^{\mathrm{a}}$ & $116( \pm 4.0)^{\mathrm{b}}$ & $156( \pm 10.2)^{\mathrm{c}}$ & $124( \pm 6.4)^{\mathrm{b}}$ & $<0.0001$ & $<0.0001$ \\
\hline $\operatorname{DIC}\left(\mathrm{mmol} \mathrm{l}^{-1}\right)$ & $1.96( \pm 0.19)$ & $1.83( \pm 0.082)$ & $1.84( \pm 0.155)$ & $1.899( \pm 0.139)$ & ns & \\
\hline $\mathrm{CO}_{2}+\mathrm{HCO}_{3}^{-}\left(\mathrm{mmol} \mathrm{l}^{-1}\right)$ & $1.85( \pm 0.14)$ & $1.70( \pm 0.13)$ & $1.56( \pm 0.22)$ & $1.74( \pm 0.16)$ & ns & \\
\hline $\begin{array}{l}\text { Sheltered site } \\
\mathrm{pH}\end{array}$ & $8.22( \pm 0.091)^{\mathrm{a}}$ & $8.67( \pm 0.029)^{\text {ac }}$ & $8.76( \pm 0.03)^{\mathrm{b}}$ & $8.53( \pm 0.049)^{\mathrm{bc}}$ & $<0.0001$ & $<00001$ \\
\hline $\mathrm{O}_{2}$ saturation (\%) & $94( \pm 9.0)^{\mathrm{a}}$ & $119( \pm 4.2)^{\mathrm{b}}$ & $133( \pm 7.5)^{\mathrm{cd}}$ & $\begin{array}{l}8.33( \pm 0.049)^{\mathrm{be}} \\
129( \pm 6.4)^{\mathrm{bd}}\end{array}$ & $\begin{array}{l}<0.0001 \\
<0.0001\end{array}$ & $\begin{array}{l}<0.0001 \\
<0.0001\end{array}$ \\
\hline $\operatorname{DIC}\left(\mathrm{mmol} \mathrm{l}^{-1}\right)$ & $2.29( \pm 0.30)$ & $2.39( \pm 0.11)^{\mathrm{a}}$ & $2.12( \pm 0.13)^{b}$ & $2.25( \pm 0.19)$ & $<0.05$ & \\
\hline $\mathrm{CO}_{2}+\mathrm{HCO}_{3}^{-}\left(\mathrm{mmol} \mathrm{l}^{-1}\right)$ & $2.12( \pm 0.30)$ & $2.11( \pm 0.16)^{a}$ & $1.70( \pm 0.20)^{b}$ & $1.94( \pm 0.25)$ & $<0.05$ & \\
\hline
\end{tabular}




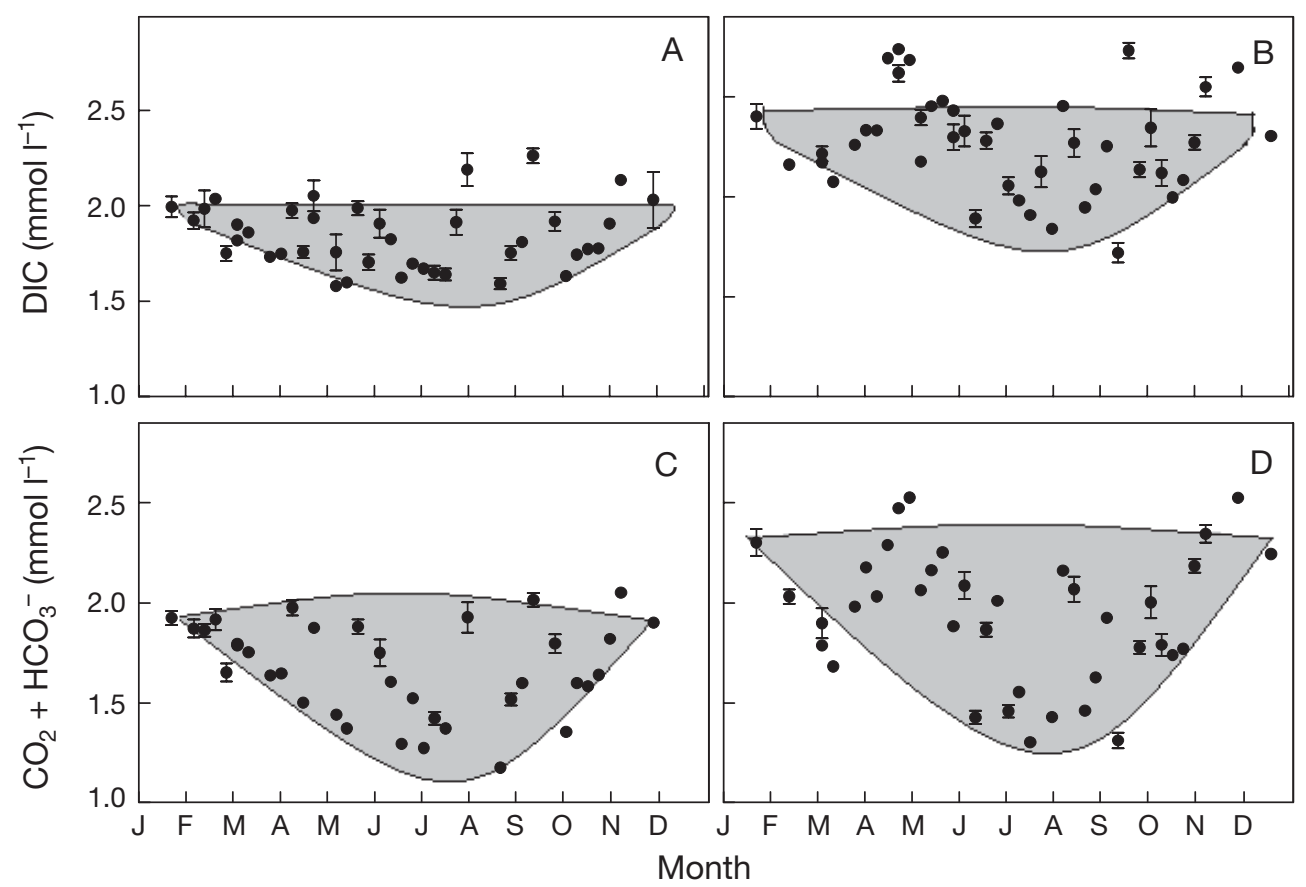

Fig. 4. Seasonal variations in dissolved inorganic carbon and available inorganic carbon at (A,C) wave-exposed and (B,D) sheltered sites from June 2005 to May 2006. Values are means \pm SE, $n=3$. Shading indicates seasonal pattern of inorganic carbon concentrations

Average inorganic carbon concentrations at $20 \mathrm{~cm}$ depth were significantly lower (Student's $t$-test, $\mathrm{p}<$ $0.001)$ at the exposed site (DIC $=1.87 \pm 0.03 \mathrm{mmol} \mathrm{l}^{-1}$ and $\left[\mathrm{CO}_{2}+\mathrm{HCO}_{3}^{-}\right]=1.69 \pm 0.04 \mathrm{mmol} \mathrm{l}^{-1}$ ) than at the sheltered site $\left(\mathrm{DIC}=2.27 \pm 0.04 \mathrm{mmol} \mathrm{l}^{-1}\right.$ and $\left[\mathrm{CO}_{2}+\right.$ $\left.\left.\mathrm{HCO}_{3}{ }^{-}\right]=1.94 \pm 0.05\right)$.

\section{Diurnal variations}

Diurnal variations in $\mathrm{pH}$ were measured at the waveexposed site at 3 water depths (Fig. 5). Diurnal variations were observed at all 3 depths but the variation decreased with increasing water depth $(\mathrm{CV}=5.6 \%$ at $20 \mathrm{~cm}, 3.8 \%$ at $40 \mathrm{~cm}$ and $2.6 \%$ at $60 \mathrm{~cm}$ ). pH increased during the early morning hours to nearly $\mathrm{pH} 9$ and stayed at this high level until 18:00 $\mathrm{h}$ when lack of photosynthesis and increased respiration caused a decrease in $\mathrm{pH}$. $\mathrm{pH}$ was significantly lower during the night than during the day (Mann-Whitney $U$-test, $\mathrm{p}<$ 0.001) and significantly different at the 3 water depths (Kruskal-Wallis test, $\mathrm{p}<0.001$ ). Average $\mathrm{pH}$ at night $(20: 00$ to $06.00 \mathrm{~h})$ was $7.8 \pm 0.03,8.1 \pm 0.03$ and $8.2 \pm$ 0.02 for 20,40 and $60 \mathrm{~cm}$ depths, respectively, while average $\mathrm{pH}$ during the day (06:00 to 20:00 h) was $8.6 \pm$ $0.03,8.6 \pm 0.02$ and $8.5 \pm 0.02$ for 20,40 and $60 \mathrm{~cm}$ depths, respectively. Maximum $\mathrm{pH}$ measured during these $3 \mathrm{~d}$ was $9.1,9.0$ and 8.9 at the 20, 40 and $60 \mathrm{~cm}$ depths, respectively.
Oxygen concentrations in the water at the $40 \mathrm{~cm}$ site showed the same diurnal pattern as $\mathrm{pH}$ (Fig. 6). During the night, the water was not saturated with oxygen $(91 \pm 1.3 \%)$, while during the day it was supersaturated most of the time (e.g. 25 percentile $=125 \%$ ).

The concentration of inorganic carbon also showed diurnal variability (Fig. 7), but the differences were not significant (Mann-Whitney $U$-test, $\mathrm{p}=0.98$ ). During the night (20:00 to 06:00 h) the inorganic carbon concentrations were 1.8 to $2.3 \mathrm{mmol} \mathrm{l}^{-1} \mathrm{CO}_{2}+\mathrm{HCO}_{3}{ }^{-}$, with lowest values in the late evening and highest values in the early morning. During the day (06:00 to 20:00 h) average inorganic carbon concentrations were 1.5 to $1.6 \mathrm{mmol}\left[\mathrm{CO}_{2}+\mathrm{HCO}_{3}^{-}\right] \mathrm{l}^{-1}$. Inorganic carbon concentrations were significantly higher at the lowest water depth than at the 2 other depths (Kruskal-Wallis test, $\mathrm{p}<0.001$ ).

\section{Photosynthesis as a function of inorganic carbon concentration and $\mathrm{pH}$}

Photosynthesis increased hyperbolically with increasing concentrations of available inorganic carbon at both $\mathrm{pH}$ levels in all 4 species (Fig. 8). The maximum photosynthetic rates $\left(P_{\max }\right)$ measured at $\mathrm{pH} 8$ were significantly higher in Ulva spp. and Ceramium rubrum than in the two Fucus species (Table 2, Student's $t$-test, $p<0.01$ in all cases). The maximum photosynthetic 


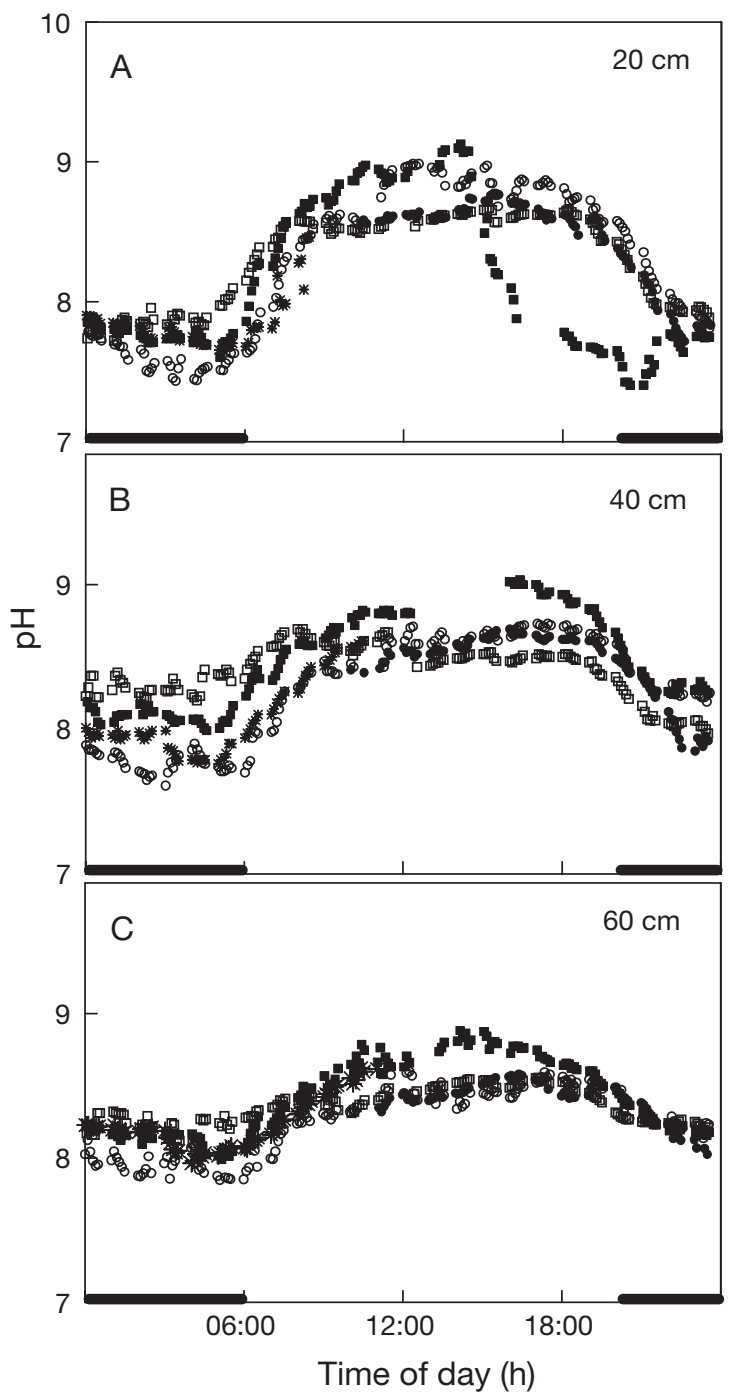

Fig. 5. Diurnal variations in $\mathrm{pH}$ at 20,40 and $60 \mathrm{~cm}$ depths at wave-exposed study site in late May 2005. Each day has a separate symbol. Night hours indicated by black bars on $X$-axis

rates measured at $\mathrm{pH} 9.3$ were 41 to $78 \%$ (23.4 to $5.6 \mathrm{mg} \mathrm{O}_{2} \mathrm{~g}_{\text {dry }} \mathrm{wt} \mathrm{h}^{-1}$ ) lower than when measured at $\mathrm{pH}$ 8. The difference was significant for all species except Ulva spp. (Student's $t$-test, $\mathrm{p}<0.05$ ).

Half-saturation concentrations $\left(K_{\mathrm{m}}\right)$ measured at pH 8 were 0.76 to $1.13 \mathrm{mmol} \mathrm{l}^{-1} \mathrm{CO}_{2}+\mathrm{HCO}_{3}^{-}$. In Fucus serratus photosynthesis was saturated with available inorganic carbon at a significantly lower concentration at pH 9.3 than at pH 8 (Student's $t$-test, p = 0.003), suggesting that photosynthesis at $\mathrm{pH} 9.3$ saturates at lower inorganic carbon concentrations. Although the same tendency was observed in the other 2 species, this could not be supported statistically.

Photosynthesis measurements at pH 9.3 for Fucus serratus that had been acclimated to $\mathrm{pH} 8$ or to 9.3 , revealed a similar photosynthetic response as a function

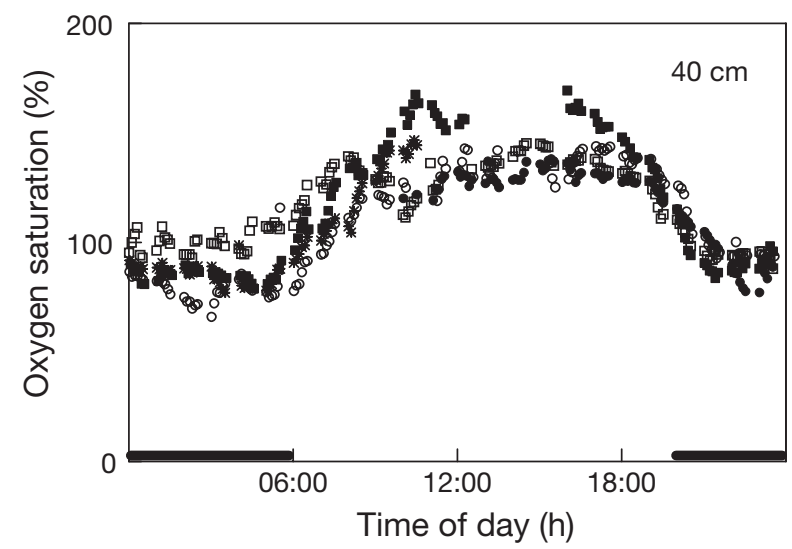

Fig. 6. Diurnal variations in oxygen saturation (\%) at $40 \mathrm{~cm}$ depth at wave-exposed study site in late May 2005. Each day has a separate symbol. Night hours indicated by black bars on $x$-axis

of inorganic carbon availability (Student's $t$-test, $\mathrm{p}>$ 0.05, Table 3, Fig. 9). However, F. serratus that had been acclimated to $\mathrm{pH} 9.3$ but subsequently exposed to pH 8 during measurements of photosynthesis had not only a significantly higher $P_{\max }$ (Student's $t$-test, $\mathrm{p}=$ 0.005 ), but also a significantly higher $K_{\mathrm{m}}$ (Student's $t$ test, $\mathrm{p}=0.02$ ) than specimens that had been acclimated to $\mathrm{pH} 8$.

\section{DISCUSSION}

\section{Level and variability of $\mathrm{pH}$ in shallow-water habitats}

This study has shown that $\mathrm{pH}$ is higher and more variable in marine shallow-water habitats than previously thought. Although it is well known from laboratory experiments that macroalgal species from shallow water in a closed system are able to increase the $\mathrm{pH}$ of the surrounding water to high levels (Maberly 1990, Murru \& Sandgren 2004), only a few natural marine habitats have been recognized a experiencing high $\mathrm{pH}$ (e.g. small, enclosed rock-pools, Larsson et al. 1997). The occurrence of high $\mathrm{pH}$ from spring to autumn at both the sheltered and the exposed site suggests that marine shallow-water habitats in general may experience high $\mathrm{pH}$ during a large part of the growth season.

The seasonal and diurnal variations reflected the distribution of available irradiance. Spring and autumn changes in $\mathrm{pH}$ were significantly related to changes in irradiance but not to change in temperature, suggesting that temperature plays a lesser role than irradiance in the seasonal differences in community photosynthetic production. This is in agreement with recent studies on community photosynthesis which have shown that the photosynthetic characteristics of communities vary but little during the year and that irradiance is the main 

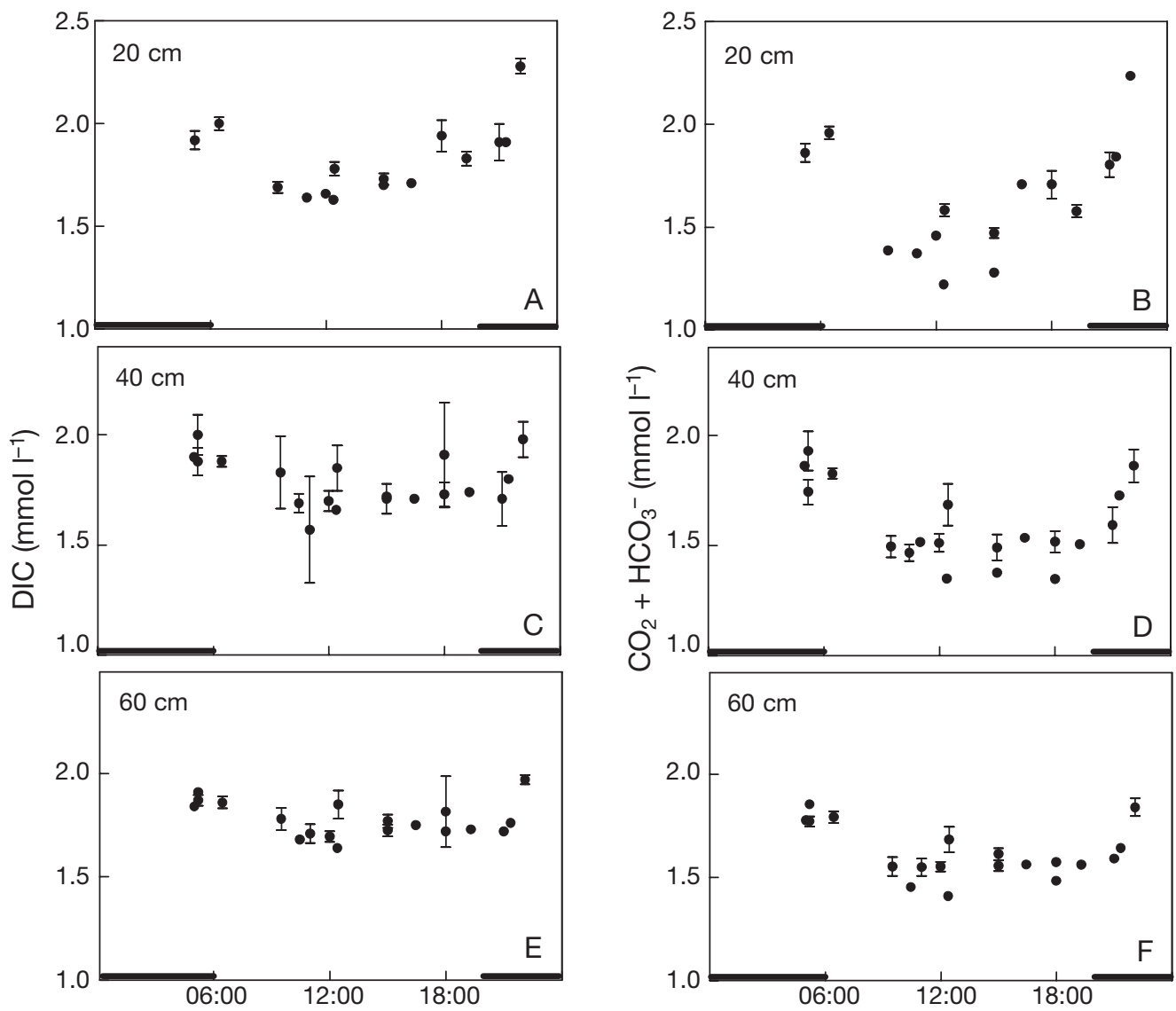

Time of day (h)

Fig. 7. Diurnal variations in dissolved inorganic carbon and available inorganic carbon (mean $\pm \mathrm{SE}, \mathrm{n}=3$ ) at 20,40 and $60 \mathrm{~cm}$ depths at wave-exposed study site in late May 2005. Night hours indicated by black bars on $x$-axis

factor determining photosynthetic production in natural macroalgal communities (Middelboe et al. 2006).

$\mathrm{pH}$ and diurnal variability were highest in the shallowest waters and decreased with increasing water depth. The reason for this is probably the interaction between the sediment and the overlying water column. In shallow water the biomass of benthic photosynthetic

Table 2. Fucus vesiculosus, F. serratus, Ceramium rubrum, Ulva spp. $P_{\max }( \pm 95 \%$ $\mathrm{CL})$ and $K_{\mathrm{m}}( \pm 95 \% \mathrm{CL})$ values for relationship between photosynthesis and inorganic carbon for 4 macroalgal species. $\mathrm{R}^{2}=$ coefficient of determination

\begin{tabular}{|lccccc|}
\hline \multirow{2}{*}{ Species } & $\mathrm{pH}$ & $P_{\max }$ & \multicolumn{2}{c|}{$K_{\mathrm{m}}\left(\mathrm{mmol}^{-1}\right)$} & \multirow{2}{*}{$\mathrm{R}^{2}$} \\
\cline { 4 - 5 } & & $\left(\mathrm{mg} \mathrm{O}_{2} \mathrm{~g} \mathrm{DW} \mathrm{h}^{-1}\right)$ & $\mathrm{CO}_{2}+\mathrm{HCO}_{3}^{-}$ & $\mathrm{DIC}$ & \\
\hline F. vesiculosus & 8 & $16.2( \pm 3.8)$ & $0.73( \pm 0.37)$ & $0.76( \pm 0.39)$ & 0.64 \\
& 9.3 & $9.4( \pm 3.6)$ & $0.88( \pm 0.68)$ & $1.73( \pm 1.34)$ & 0.58 \\
F. serratus & 8 & $17.8( \pm 3.6)$ & $1.13( \pm 0.42)$ & $1.184( \pm 0.44)$ & 0.82 \\
& 9.3 & $5.7( \pm 1.8)$ & $0.21( \pm 0.24)$ & $0.41( \pm 0.47)$ & 0.16 \\
C. rubrum & 8 & $25.2( \pm 10.1)$ & $0.88( \pm 0.72)$ & $0.93( \pm 0.75)$ & 0.65 \\
Ulva spp. & 9.3 & $5.6( \pm 5.9)$ & $0.48( \pm 0.33)$ & $0.94( \pm 0.66)$ & 0.47 \\
& 8 & $46.0( \pm 22.6)$ & $0.76( \pm 0.79)$ & $0.80( \pm 0.83)$ & 0.48 \\
& 9.3 & $23.4( \pm 4.0)$ & $0.45( \pm 0.20)$ & $0.89( \pm 0.40)$ & 0.81 \\
\hline
\end{tabular}

and respiratory organisms is much higher relative to the water volume than in deeper water. Thus, both photosynthesis and respiration from these organisms have a large influence on the water chemistry in shallow waters. In open waters, the photic zone is spatially separated from the bottom by the pycnocline, and the respiration processes in the sediment will not influence the $\mathrm{pH}$ in the photic zone. $\mathrm{pH}$ and diurnal variability in $\mathrm{pH}$ should, thus, be higher in shallow than in the open waters.

It was surprising that $\mathrm{pH}$ was not very high on calm, sunny days and that it did not steadily increase throughout the daylight hours. From pH-drift experiments in closed systems we know that the dominant species at the 2 sites, Fucus spp. and Ulva spp., are able to increase pH above 10 (Maberly 1990, Larsson et al. 1997), but in this study maximum $\mathrm{pH}$ during the day or summer rarely exceeded 9. This may have been due to continuous exchange of water with the 

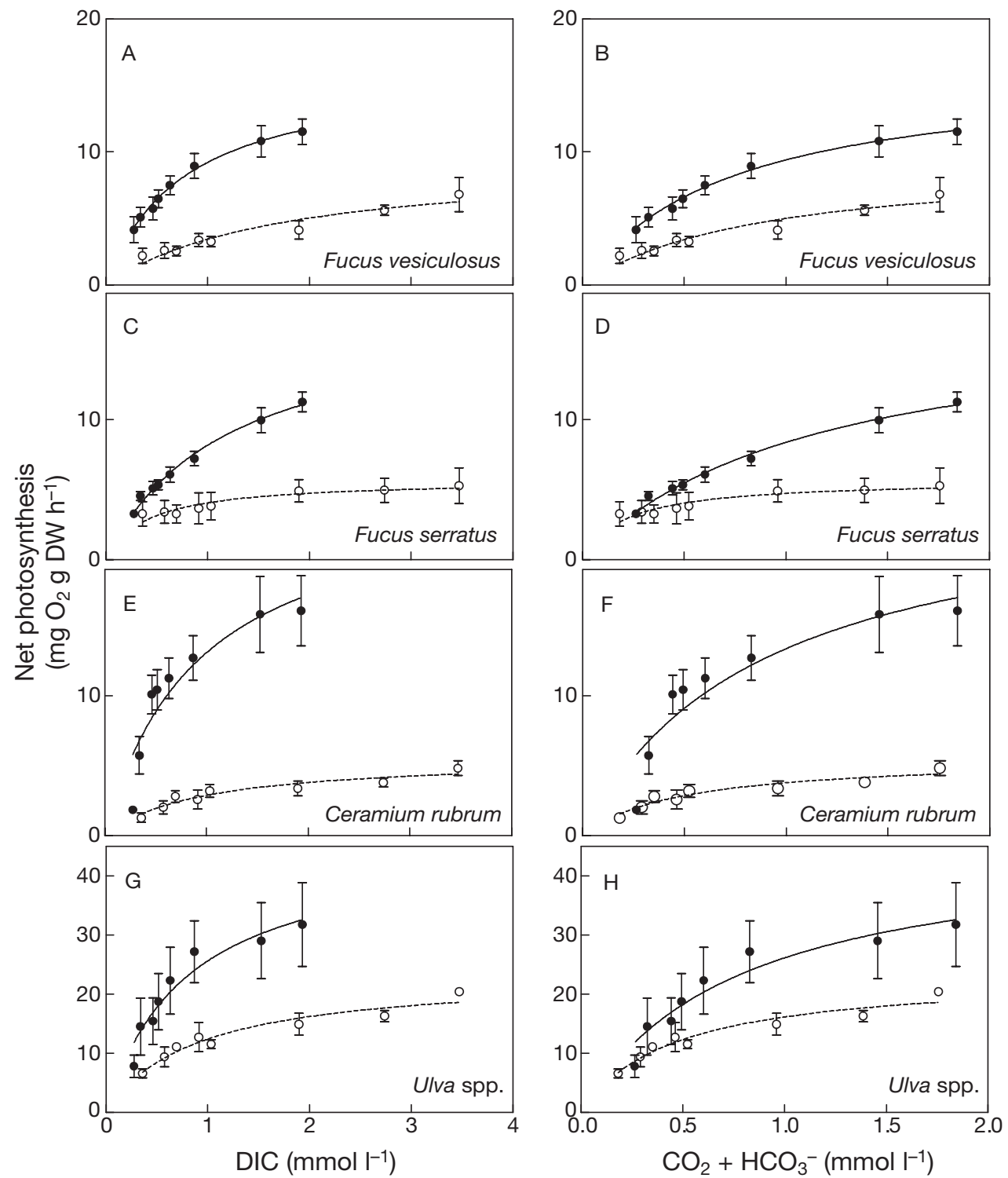

Fig. 8. Fucus vesiculosus, F. serratus, Ceramium rubrum and Ulva spp. Net photosynthesis as a function of (A,C, E, G) dissolved inorganic carbon and $(\mathrm{B}, \mathrm{D}, \mathrm{F}, \mathrm{H})$ available inorganic carbon measured at $(\mathbf{O}) \mathrm{pH} 8$ and $(\mathrm{O})$ 9.3. Values are means $\pm \mathrm{SE}_{i} \mathrm{n}=3$

surroundings and the air-water $\mathrm{CO}_{2}$ flux, which is assumed to ensure a relatively stable $\mathrm{pH}$ (about 8.2, Skirrow 1975) in the marine environment, despite high photosynthetic rates. Wind and turbulence enhance both these processes (Havskum \& Hansen 2006). On windy days the water is thus rapidly exchanged with the surrounding water and the air-water flux is high, causing $\mathrm{pH}$ to decrease. There were therefore large variations in $\mathrm{pH}$ between sampling days at both the exposed and the sheltered site. Also, at the exposed site, average $\mathrm{pH}$ was slightly lower than at the sheltered site (Fig. 3), possibly due to differences in isolation and exposure.

Another possible explanation for the lack of very high $\mathrm{pH}$ levels is that high $\mathrm{pH}$ alters the direction and magni- tude of the air-water $\mathrm{CO}_{2}$ flux (Stumm \& Morgan 1996). $\mathrm{CO}_{2}$ efflux from the water to the atmosphere occurs when the water is supersaturated with $\mathrm{CO}_{2}$, while influx occurs when the dissolved $\mathrm{CO}_{2}$ concentration is below air equilibrium at the air-water interface. The $\mathrm{CO}_{2}$ flux is limited by the diffusive transport across the boundary layer and the driving force for this transport is the concentration gradient. As the $\mathrm{CO}_{2}$ concentration in the water decreases and $\mathrm{pH}$ increases as a result of $\mathrm{C}$ uptake by the organisms, the water becomes undersaturated with $\mathrm{CO}_{2}$ and an efflux changes to an influx. Furthermore, the flux rate is enhanced due to the increased transformation of $\mathrm{CO}_{2}$ into $\mathrm{HCO}_{3}^{-}$at high pH (Portielje \& Lijklema 1995). This enhancement factor increases with increas- 
Table 3. Fucus serratus. $P_{\max }\left( \pm 95 \%\right.$ CL) and $K_{\mathrm{m}}( \pm 95 \% \mathrm{CL})$ values for relationship between photosynthesis and available inorganic carbon concentrations $\left(\mathrm{CO}_{2}+\mathrm{HCO}_{3}{ }^{-}\right)$for thalli acclimated (accl.) to and measured (meas.) at pH 8 and 9.3

\begin{tabular}{|c|c|c|c|}
\hline accl. & $\overline{\text { meas. }}$ & $P_{\max }$ & $K_{\mathrm{m}}$ \\
\hline 8 & 8 & $4.0( \pm 0.7)$ & $0.48( \pm 0.2)$ \\
\hline 9.3 & 9.3 & $5.0( \pm 1.2)$ & $0.75( \pm 0.38)$ \\
\hline 9.3 & 8 & $15.1( \pm 3.9)$ & $1.8( \pm 0.75)$ \\
\hline
\end{tabular}

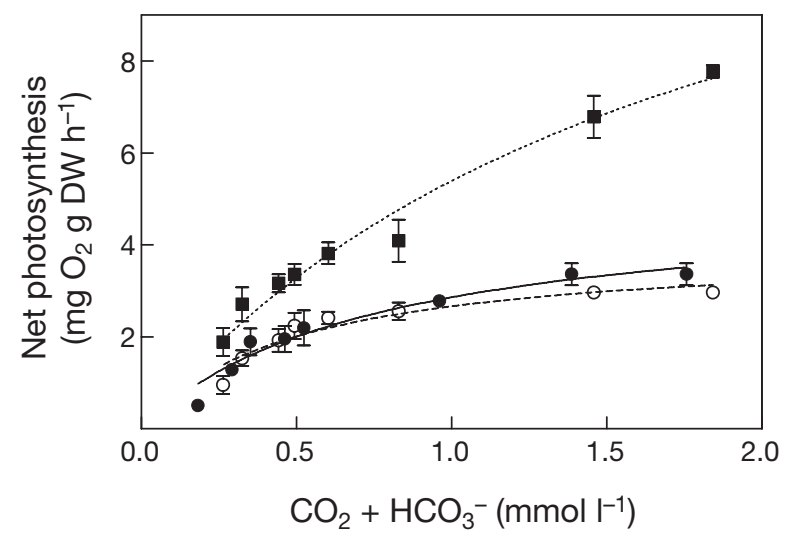

Fig. 9. Fucus serratus. Net photosynthesis as a function of available inorganic carbon (mmol $\mathrm{CO}_{2}+\mathrm{HCO}_{3}^{-} \mathrm{l}^{-1}$ ) for samples acclimated to and measured at (O) $\mathrm{pH} 8$ and $(\bullet)$ 9.3, and for samples $(\boldsymbol{\square})$ acclimated to $\mathrm{pH} 9.3$ but measured at $\mathrm{pH}$ 8. Values are means $\pm \mathrm{SE} ; \mathrm{n}=3$

ing $\mathrm{pH}$, and as a result the influx of $\mathrm{CO}_{2}$ from the atmosphere is high at high $\mathrm{pH}$. At high $\mathrm{pH}$ a further increase in $\mathrm{pH}$ is, thus, counterbalanced by an influx of $\mathrm{CO}_{2}$ from the atmosphere.

\section{Is macroalgal photosynthesis limited by inorganic carbon?}

The high DIC concentration at the sheltered site may be explained by its situation in the Roskilde Fjord, where the drainage area is rich in $\mathrm{CaCO}_{3}$ resulting in very high DIC concentrations in the coastal waters. The water at the exposed site on the other hand is a

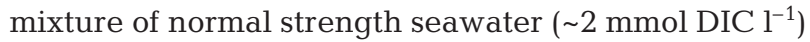
from the Kattegat and water with a relatively low content of inorganic carbon from the Baltic Sea (Thomas \& Schneider 1999). Differences in inorganic carbon content may thus be relatively large between different areas and may be especially high in estuaries surrounded by $\mathrm{CaCO}_{3}$-rich soils with a relatively small water exchange.
It is unlikely that photosynthesis was carbon-limited at the levels of DIC and $\mathrm{pH}$ measured in this study. Gross photosynthesis as a function of inorganic carbon showed that even at the lowest concentrations of available inorganic carbon measured in this study, photosynthesis of the 4 species was not limited by inorganic carbon. Published $K_{\mathrm{m}}$ values for the same and other species also suggest that almost all macroalgal species are saturated with inorganic carbon at this concentration (Sand-Jensen \& Gordon 1984, Frost-Christensen \& Sand-Jensen 1990, Johnston et al. 1992).

\section{Photosynthesis limitation at high pH}

The effect of high $\mathrm{pH}$ on macroalgal photosynthesis is often believed to be caused by a lower availability of inorganic carbon (Maberly 1990, Snoeijs et al. 2002, Murru \& Sandgren 2004). High pH may, however, have a direct effect on macroalgal physiology beside the influence of inorganic carbon utilization. Pedersen \& Hansen (2003) showed that high $\mathrm{pH}$ reduced growth of the heterotrophic protists Favella ehrenbergii, Rimostrombidium caudatum and $R$. veniliae when $\mathrm{pH}$ exceeded 8.8. These organisms do not rely on inorganic carbon uptake, and elevated $\mathrm{pH}$ may therefore affect other mechanisms such as the membrane transport processes and metabolic functions involved in internal pH regulation (Smith \& Raven 1979, Raven 1980). Alternatively, high external $\mathrm{pH}$ may cause changes in cellular content of amino acids and their relative composition, probably affecting cellular growth (Taraldsvik \& Myklestad 2000).

Some algae can acclimate their photosynthesis to high $\mathrm{pH}$, as was the case for Fucus serratus in this study. When species acclimated to $\mathrm{pH} 9.3$ were measured at $\mathrm{pH} 8$, increases in both $P_{\max }$ and $K_{\mathrm{m}}$ were statistically significantly, suggesting that acclimatization increases the efficiency of inorganic carbon uptake at high pH. F. serratus is known to use extracellular carbonic anhydrase (CAe) as a mechanism for $\mathrm{HCO}_{3}^{-}$ uptake. In other algae species, CAe has been shown to increase in periods of high $\mathrm{pH}$ and low DIC (Hobson et al. 2001). CAe activity is, however, not very effective at high pH (Larsson et al. 1997) and F. serratus is able to photosynthesize in water with a very high $\mathrm{pH}(\mathrm{pH}$ limit $=10.31$, Maberly 1990) suggesting that other mechanisms are also involved in the uptake of $\mathrm{HCO}_{3}{ }^{-}$.

In conclusion, the high $\mathrm{pH}$ measured from early spring to autumn at both sites and its influence on the photosynthetic rates of the dominant species suggests that $\mathrm{pH}$ may be an important factor for marine shallowwater primary production. However, this study comprises only a beginning, and has raised a number of new questions. (1) The results suggest that at least 
some species can acclimate and photosynthesize efficiently in waters with high $\mathrm{pH}$. We do not, however, know how general the ability to acclimate to high $\mathrm{pH}$ is or the temporal aspects of acclimatization. (2) Recent studies have shown that measurements on thallus pieces cannot always be extrapolated to whole macroalgal communities (Binzer \& Middelboe 2005) because large parts of the biomass in a community are continuously light-limited. Measurements of photosynthesis on a more relevant ecological scale (e.g. on whole communities) may therefore reveal variable responses to high $\mathrm{pH}$. (3) The growth response to high $\mathrm{pH}$ may differ from the photosynthetic response because growth integrates acclimatization and possibly involves higher maintenance costs for the algae.

Acknowledgements. This project was funded by the Villum Kann Rasmussen Foundation. We thank A. Bisgaard for technical assistance.

\section{LITERATURE CITED}

Axelsson L, Ryberg H, Beer S (1995) 2 modes of bicarbonate utilization in the marine green macroalga Ulva lactuca. Plant Cell Environ 18:439-445

Axelsson L, Larsson C, Ryberg H (1999) Affinity, capacity and oxygen sensitivity of two different mechanisms for bicarbonate utilization in Ulva lactuca L. (Chlorophyta). Plant Cell Environ 22:969-978

Binzer T, Middelboe AL (2005) From thallus to communities: scale effects and photosynthetic performance in macroalgae communities. Mar Ecol Prog Ser 287:65-75

Björk M, Axelsson L, Beer S (2004) Why is Ulva intestinalis the only macroalga inhabiting isolated rockpools along the Swedish Atlantic coast? Mar Ecol Prog Ser 284:109-116

Frost-Christensen H, Sand-Jensen K (1990) Growth rate and carbon affinity of Ulva lactuca under controlled levels of carbon, pH and oxygen. Mar Biol 104:497-501

Gonzalez JA, Calbo J (2002) Modelled and measured ratio of PAR to global radiation under cloudless skies. Agr For Meteorol 110:319-325

Hansen PJ (2002) Effect of high pH on the growth and survival of of marine phytoplankton: implications for species succesion. Aquat Microb Ecol 28:279-288

Havskum H, Hansen PJ (2006) Net growth of the bloomforming dinoflagellate Heterocapsa triquetra and $\mathrm{pH}$ : why turbulence matters. Aquat Microb Ecol 42:55-62

Hellblom F, Beer S, Björk M, Axelsson L (2001) A buffer sensitive inorganic carbon utilisation system in Zostera marina. Aquat Bot 69:55-62

Hinga KR (2002) Effects of $\mathrm{pH}$ on coastal marine phytoplankton. Mar Ecol Prog Ser 238:281-300

Hobson LA, Hanson CE, Holeton C (2001) An ecological basis for extracellular carbonic anhydrase in marine unicellular algae. J Phycol 37:717-723

Johnston AM, Maberly SC, Raven JA (1992) The acquisition of inorganic carbon by four red algae. Oecologia 92: 317-326

Larsson C, Axelsson L, Ryberg H, Beer S (1997) Photosynthetic carbon utilization by Enteromorpha intestinalis
(Chlorophyta) from a Swedish rockpool. Eur J Phycol 32: 49-54

Maberly SC (1990) Exogenous sources of inorganic carbon for photosynthesis by marine macroalgae. J Phycol 26: 439-449

Macedo MF, Duarte P, Mendes P, Ferreira JG (2001) Annual variation of environmental variables, phytoplankton species composition and photosynthetic parameters in a coastal lagoon. J Plankton Res 23:719-732

Mackereth FJH, Heron J, Talling JF (1978) Water analysis: some revised methods for limnologists. Freshwater Biological Association, Windermere

Menendez M, Martinez M, Comin FA (2001) A comparative study of the effect of $\mathrm{pH}$ and inorganic carbon resources on the photosynthesis of three floating macroalgae species of a Mediterranean coastal lagoon. J Exp Mar Biol Ecol 256:123-136

Middelboe AL, Sand-Jensen K, Binzer T (2006) Highly predictable photosynthetic characteristics in natural macroalgal communities from incoming and absorbed light. Oecologia 150:464-476

Murru M, Sandgren CD (2004) Habitat matters for inorganic carbon acquisition in 38 species of red macroalgae (Rhodophyta) from Puget Sound, Washington, USA. J Phycol 40:837-845

Pearson GA, Serrao EA, Brawley SH (1998) Control of gamete release in fucoid algae: sensing hydrodynamic conditions via carbon acquisition. Ecology 79:1725-1739

Pedersen MF, Hansen PJ (2003) Effects of high pH on the growth and survival of six marine heterotrophic protists. Mar Ecol Prog Ser 260:33-41

Plath DC, Johnson KS, Pytkowicz RM (1980) The solubility of calcite-probably containing magnesium - in seawater. Mar Chemi 10:9-29

Portielje R, Lijklema L (1995) Carbon dioxide fluxes across the air-water interface and its impact on carbon availability in aquatic systems. Limnol Oceanogr 40:690-699

Raven JA (1980) Nutrient transport in microalgae. Adv Micro Physiol 21:47-226

Raven JA, Ball LA, Beardall J, Giordano M, Maberly SC (2005) Algae lacking carbon-concentrating mechanisms. Can J Bot 83:879-890

Revsbech NP (1989) An oxygen microsensor with a guard cathode. Limnol Oceanogr 34:474-478

Sand-Jensen K, Gordon DM (1984) Differential ability of marine and freshwater macrophytes to utilize $\mathrm{HCO}_{3}{ }^{-}$and $\mathrm{CO}_{2}$. Mar Biol 80:547-253

Skirrow G (1975) The dissolved gases - carbon dioxide. In: Riley JP, Skirrow G (eds) Chemical oceanography. Academic Press, New York, p 1-92

Smith FA, Raven JA (1979) Intracellular pH and its regulation. Annu Rev Plant Physiol 30:289-311

Snoeijs P, Klenell M, Choo KS, Comhaire I, Ray S, Pedersen M (2002) Strategies for carbon acquisition in the red marine macroalga Coccotylus truncatus from the Baltic Sea. Mar Biol 140:435-444

Stumm W, Morgan J (1996) Aquatic chemistry. Chemical equilibria and rates in natural waters. John Wiley \& Sons, New York

Taraldsvik M, Myklestad SM (2000) The effect of pH on growth rate, biochemical composition and extracellular carbohydrate production of the marine diatom Skeletonema costatum. Eur J Phycol 35:189-194

Thomas H, Schneider B (1999) The seasonal cycle of carbon dioxide in Baltic Sea surface waters. J Mar Syst 22:53-67 